\title{
The time of infection of apples by Botrytis cinerea Pers.
}

\author{
HANNA BRYK \\ Institute of Pomology and Floriculture, ul. Pomologiczna 18, \\ 96-100 Skierniewice, Poland
}

(Received: March 28, 1985)

\begin{abstract}
The time of infection of apple fruits by Botrytis cinerea Pers. was studied. Artificial inoculations with conidial suspensions of $B$. cinerea were done at different stages of fruit developmment (flowers, sets, fruits). In autumn the apples were harvested and stored at a temperature of $2{ }^{\circ} \mathrm{C}$ for 4 months after which rotting caused by $B$. cinerea was evaluated. $B$. cinerea presence in the calyx of apples was checked throughout the growing season. This was done by plating flowers, apple and set calyces on PDA medium. Latent infection of apples by $B$. cinerea was found. The infection took place in the orchard and the pathogen survived latently in the calyx; disease symptoms appeared in storage. Infection is possible during the whole vegetative season, but the most important time is flowering and just before or just after harvest of apples.
\end{abstract}

\section{INTRODUCTION}

In Poland, gray mold is one of the main diseases of apples kept in cold storage (B ry k, 1982). This disease is caused by Botrytis cinerea Pers. (Botryotinia fuckeliana (de Bary) Whetzel).

In spite of the abundance of literature on this fungus, the time and mode of infection of apples still has been disputed. Pierson et al. (1971) believe that apples are infected in orchards by conidia. According to them, the spores lodge in the calyx or stem depression, where they germinate and attack the stem or calyx parts. Under favorable conditions, the mycelium penetrates into the flesh of the apple, causing it to rot.

Infection of apple flowers by $B$. cinerea has been described in literature in relationship to dry eye rot of apples (W il k in s o n, 1943; Tronsmo and $\mathrm{Raa}$ a 1977). Morgat el al. (1977) hold the opinion. 
that infection of apple flowers may also influence rotting of apples during storage.

The objective of this study was to determine the stage at which the infection of apples by $B$. cinerea takes place and to establish the role of latent infection in the rotting of apples during storage.

\section{MATERIAL AND METHODS}

The experiment was set up in the Orchard of the Institute of Pomology and Floriculture in Skierniewice on 11 years old trees of the 'Bancroft' variety and in the Experimental Station of the Institute of Pomology and Floriculture in Dąbrowice on 16 years old trees of the same variety. In earlier author's studies (unpublished), the 'Bancroft' variety was found to be very sensitive to infection by $B$. cinerea. The experiment was based on artificial infection of apples at different stages of development (flowers, sets, mature apples) after which they were picked and stored in a cold storage chamber and the degree of rotting caused by $B$. cinerea was determined.

The experiment consisted of the following combinations:

I - control combination (no inoculation),

II - inoculation of flowers,

III - flowers sprayed with $0.25 \%$ Euparen, inoculation of flowers after $24 \mathrm{~h}$,

IV - inoculation of sets 1 month after blooming,

$\mathrm{V}$ - inoculation of apples 2 weeks before picking,

VI - inoculation of apples directly after picking.

The experiment in Dabrowice included the 6 listed combinations, the one in Skierniewice, 4 (I, II, IV, V). Both experiments employed a zonal arrangement with 5 trees in each combination. A replication consisted of 1 tree (all of the flowers, sets and apples on it). One tree for protection was left between each combination to eliminate the possibility of the inoculum being carried over.

Inoculation was done by spraying the flowers, sets or apples with an aqueous suspension of $B$. cinerea conidia at a density of $3 \times 10^{6}$ spores $/ \mathrm{ml}$ and germination capacity of $96-98 \%$. The inoculation was done with a "Spraymist" hand sprayer.

The experiment was set up in production sectors where, until blooming, the trees were under standard chemical protection schemes. Inoculation of flowers was done at full bloom (combinations II and III). Five days after inoculation, the critical period during which scab (Venturia inaequalis (Cooke) Aderh.) should be controlled, ensued. In order to be sure that the treatment against the scab did not influence the 
process of infection under study here, all of the flowers on the experimental trees were covered by polyethylene isolators. From this time on, all of these trees were excluded from further treatment againts diseases.

The presence of the fungus on apples was checked for several times during their development and storage. Because the rotting caused by $B$. cinerea most often begins at the calyx, it was supposed that the fungus first establishes itself there, and then penetrates into the flesh, causing it to rot. In order to check for the presence of the fungus on the apple, calyces removed from apple sets or mature fruit were placed on agar-potato medium (PDA) in Petri dishes. The flowers and calyces were separated into petals, stamens and sepals before they were placed on the medium. This was done in order to establish which part of the flower or calyx was most often settled by the fungus. The time scheme of sampling the calyces or flowers is given in Table 1. Depending on the date, either 100 flowers or 50 set calyces or 50 apple calyces were tested. After incubation for a few days at room temperature, the fungi grew up from the studied organs were identified and the percentage of flower or calyx parts contaminated with $B$. cinerea was computed.

Apples from all of the experimental trees were picked at the beginning of October. One box $(20 \mathrm{~kg})$ from each tree was set aside for storage. One box of apples constituted one replication; each combination had 5 replications. Combination $\mathrm{V}$ in the experiment at Dąbrowice consisted of apples inoculated immediately after being picked. Part of the remaining apples from the control combination were placed calyx-up and sprayed with an aqueous suspension of conidia at a density of $3 \times 10^{6}$ spores $/ \mathrm{ml}$. Next, the apples were placed in 5 boxes and together with the remaining apples, put into cold storage at $2^{\circ} \mathrm{C}$.

All of the apples were stored for 4 months after which they were evaluated by counting the number of healthy and rotted apples and computing the percentage of apples attacked by $B$. cinerea. The results were analysed statistically by the variance method, the averages were compared by Student's t-test.

\section{RESULTS}

The method of plating different calyx and flower parts on a nutrient medium enabled the presence of $B$. cinerea on apples to be followed all through their development. Table 2 presents the occurrence of $B$. cinerea on flowers and set calyces. Twenty-four hours after inoculation of flowers, the fungus was found to have colonized the petals, stamens and pistils to the greatest extent, whereas the sepals were least attacked. 
Table 1

The schedule according to which flowers, sets and apples were collected for testing on medium for the presence of $B$. cinerea

\begin{tabular}{|c|c|c|c|c|c|c|}
\hline \multirow[b]{2}{*}{ Time of sampling } & \multicolumn{6}{|c|}{ Combination } \\
\hline & $\begin{array}{c}\text { I } \\
\text { control } \\
\text { (no inoculation) }\end{array}$ & $\begin{array}{l}\text { II } \\
\text { inoculation of } \\
\text { flowers }\end{array}$ & $\begin{array}{l}\text { III } \\
\text { Euparen }+ \text { inocu- } \\
\text { lation of flowers }\end{array}$ & $\begin{array}{c}\text { IV } \\
\text { inoculation of } \\
\text { scts }\end{array}$ & $\begin{array}{c}\mathrm{V} \\
\text { inoculation of apples } \\
\text { before picking }\end{array}$ & $\begin{array}{c}\text { VI } \\
\text { inoculation of apples } \\
\text { after picking }\end{array}$ \\
\hline $24 \mathrm{~h}$ after inoculation of & & & & & & \\
\hline $\begin{array}{l}\text { flowers } \\
1 \text { month after inoculation } \\
\text { of flowers }\end{array}$ & $x$ & $x$ & $x$ & & & \\
\hline $\begin{array}{l}\text { of flowers } \\
4 \text { days after inoculation of } \\
\text { sets }\end{array}$ & $x$ & $x$ & $x$ & $x$ & & \\
\hline $\begin{array}{l}\text { Directly after picking of } \\
\text { apples } \\
\text { After cold storage of apples for }\end{array}$ & $x$ & $\times$ & $x$ & $x$ & $x$ & \\
\hline 4 months & $x$ & $x$ & $x$ & $x$ & $x$ & $x$ \\
\hline
\end{tabular}


Ta ble 2

The occurrence of $B$. cinerea on apple flowers and in the calyces of apple sets ( $\%$ colonized organs)

\begin{tabular}{|c|c|c|c|c|c|c|c|c|}
\hline \multirow{3}{*}{$\begin{array}{c}\text { Time of observation } \\
\text { Flower (calyx) } \\
\text { parts }\end{array}$} & \multicolumn{3}{|c|}{$24 \mathrm{~h}$ after inoculation of flowers } & \multicolumn{3}{|c|}{1 month after inoculation of flowers } & \multicolumn{2}{|c|}{4 days after inoculation of sets } \\
\hline & \multicolumn{8}{|c|}{ Combination } \\
\hline & $\begin{array}{l}\text { I } \\
\text { control (no } \\
\text { inoculation) }\end{array}$ & $\begin{array}{l}\text { II } \\
\text { inoculation of } \\
\text { flowers }\end{array}$ & $\begin{array}{l}\text { III } \\
\text { Euparen }+ \text { ino- } \\
\text { culation of } \\
\text { flowers }\end{array}$ & $\begin{array}{l}\text { I } \\
\text { control (no } \\
\text { inoculation) }\end{array}$ & $\begin{array}{l}\text { II } \\
\text { inoculation of } \\
\text { flowers }\end{array}$ & $\begin{array}{l}\text { III } \\
\text { Euparen }+ \text { ino- } \\
\text { culation of } \\
\text { flowers }\end{array}$ & $\begin{array}{c}\text { I } \\
\text { control (no } \\
\text { inoculation) }\end{array}$ & $\begin{array}{c}\text { IV } \\
\text { inoculation of } \\
\text { sets }\end{array}$ \\
\hline \multicolumn{9}{|l|}{ Skierniewice } \\
\hline Petals & $24.0 b^{*}$ & $98.6 \mathrm{e}$ & 一 & - & - & - & - & - \\
\hline Pistil & $46.6 \mathrm{c}$ & $93.2 \mathrm{~d}$ & 一 & $10.0 \mathrm{a}$ & $48.0 \mathrm{~b}$ & - & $6.0 \mathrm{a}$ & $28.0 \mathrm{~b}$ \\
\hline Stamens & $34.4 \mathrm{bc}$ & $100.0 \mathrm{e}$ & - & $2.0 \mathrm{a}$ & $40.0 \mathrm{~b}$ & 一 & $6.0 \mathrm{a}$ & $24.0 \mathrm{~b}$ \\
\hline Sepals & $12.0 \mathrm{a}$ & $34.6 \mathrm{bc}$ & - & $4.0 \mathrm{a}$ & $30.0 \mathrm{~b}$ & 一 & $6.0 \mathrm{a}$ & $16.0 \mathrm{ab}$ \\
\hline \multicolumn{9}{|l|}{ Dąbrowice } \\
\hline Petals & $29.0 \mathrm{ab}$ & $99.0 \mathrm{~d}$ & $40.0 \mathrm{~b}$ & $\ldots$ & - & $\ldots$ & 一 & - \\
\hline Pistil & $25.0 \mathrm{ab}$ & $89: 0 \mathrm{~d}$ & $72.0 \mathrm{c}$ & $16.0 \mathrm{~b}$ & $44.0 \mathrm{c}$ & $8.0 \mathrm{ab}$ & $20.0 \mathrm{~b}$ & $30.0 \mathrm{~b}$ \\
\hline Stamens & $44.0 \mathrm{~b}$ & $92.0 \mathrm{~d}$ & $55.0 \mathrm{bc}$ & $8.0 \mathrm{ab}$ & $40.0 \mathrm{c}$ & $4.0 \mathrm{ab}$ & $6.0 \mathrm{a}$ & $18.0 \mathrm{~b}$ \\
\hline Sepals & $20.0 \mathrm{a}$ & $68.0 \mathrm{c}$ & $17.0 \mathrm{a}$ & $4.0 \mathrm{ab}$ & $26.0 \mathrm{bc}$ & $2.0 \mathrm{a}$ & $6.0 \mathrm{a}$ & $16.0 \mathrm{~b}$ \\
\hline
\end{tabular}

* Statistical analysis was carried out separately for each time of observation and locality. $\mathbf{P}=0.05$. 
The use of Euparen before inoculation (combination III) significantly decreased the percent of flower parts colonized by the fungus, in comparison with inoculated flowers (combination II). The presence of the fungus was also found on flowers which had not been inoculated, and here too, the most attacked were the stamen and pistils. This indicates that natural infection occurs. The analysis of the calyces of sets one month after the inoculation of flowers showed that the fungus was found there, although to a smaller degree than in the flowers. The flowers which were attacked to a high degree by $B$. cinerea, underwent necrosis, dried up and fell off; fruit developed only from healthy or slightly stricken flowers. Inoculation of flowers brought about greater $B$. cinerea occurrence in the calyces of sets formed from these flowers than in the calyces of flowers not inoculated. The use of Euparen, however, before inoculation of flowers significantly decreased the percent of flower parts colonized by the fungus. Inoculation of the fruit sets caused a higher number of calyces of these sets to be colonized, in comparison with untreated sets, however, to a lesser extent than in the case of inoculating flowers (Table 2).

Directly after picking, $B$. cinerea was found in the highest numbers in the calyces of those apples which developed from inoculated flowers (Table 3). The remaining times of inoculation did not play such a significant role in the contamination of apples. The use of Euparen during blooming significantly reduced the occurrence of the fungus. The inoculation of apples 2 weeks before picking caused only the increased settling of sepals in both experiments.

T a ble 3

The occurrence of $B$. cinerea in apple calyces directly after picking ( $\%$ colonized organs)

\begin{tabular}{|c|c|c|c|c|c|}
\hline \multirow[b]{2}{*}{ Calyx parts } & \multicolumn{5}{|c|}{ Combination } \\
\hline & $\begin{array}{c}\text { I } \\
\text { control } \\
\text { (no ino- } \\
\text { culation) }\end{array}$ & $\begin{array}{c}\text { II } \\
\text { inoculation } \\
\text { of flowers }\end{array}$ & $\begin{array}{c}\text { III } \\
\text { Euparen }+ \\
\text { inoculation } \\
\text { of flowers }\end{array}$ & $\begin{array}{c}\text { IV } \\
\text { inoculation } \\
\text { of sets }\end{array}$ & $\begin{array}{c}\mathbf{V} \\
\text { inoculation } \\
\text { of apples } \\
\text { before pi- } \\
\text { cking }\end{array}$ \\
\hline \multicolumn{6}{|l|}{ Skierniewice } \\
\hline Pistil & $10.0 \mathrm{a}^{*}$ & $68.0 \mathrm{c}$ & - & $20.0 \mathrm{a}$ & $18.0 \mathrm{a}$ \\
\hline Stamens & $10.0 \mathrm{a}$ & $60.0 \mathrm{bc}$ & 一 & $26.0 \mathrm{a}$ & $20.0 \mathrm{a}$ \\
\hline Sepals & $10.0 \mathrm{a}$ & $58.0 \mathrm{bc}$ & - & $16.0 \mathrm{a}$ & $48.0 \mathrm{~b}$ \\
\hline \multicolumn{6}{|l|}{ Dąbrowice } \\
\hline Pistil & $24.0 \mathrm{ab}$ & $48.0 \mathrm{c}$ & 18.ab & $24.0 \mathrm{ab}$ & $16.0 \mathrm{ab}$ \\
\hline Stamens & $16.0 \mathrm{ab}$ & $40.0 \mathrm{bc}$ & $8.0 \mathrm{a}$ & $26.0 \mathrm{~b}$ & $16.0 \mathrm{ab}$ \\
\hline Sepals & $18.0 \mathrm{ab}$ & $40.0 \mathrm{bc}$ & $12.0 \mathrm{ab}$ & $20.0 \mathrm{ab}$ & $26.0 \mathrm{~b}$ \\
\hline
\end{tabular}

* Statistical analysis was carried aut separately for the experiments at Skierniewice and Dabrowice. $\mathbf{P}=\mathbf{0 . 0 5}$. 
After 4 months of cold storage, the rotting of apples due to $B$. cinerea was evaluated. It was found that the apples from Skierniewice were affected to a higher degree than the apples from Dąbrowice (Table 4). In Skierniewice, a significant difference was found between the rotting of apples inoculated before harvest and those not inoculated. There were no statistically significant differences found between the rotting of apples developed from inoculated flowers, those inoculated at the set stage and control apples, although a slight tendency was observed for greater rotting of apples developed from inoculated flowers. In the experiment at Dąbrowice, apples developed from inoculated flowers and those inoculated after picking were affected to the greatest extent. The use of Euparen before the inoculation of flowers decreased the rotting of apples, but did not completely limit the occurrence of the disease. In contrast to the experiment at Skierniewice, in Dąbrowice, the inoculaticn of apples before picking did not cause increased rotting during storage. The reason for this could have been the rain which fell a few hours after inoculation and probably washed off the conidia previously sprayed on the apples. Support for this reasoning comes from the fact that a smaller percentage of apple calyces was found to be settled by $B$. cinerea in these apples in comparison with those from Skierniewice (Table 3).

When the calyces from apples remaining healthy after the storage period were placed once again on the medium, it was found that $B$. cinerea was still present in them, although in a smaller percent than before the apples had been placed in cold storage (Table 5 ). The calyces of apples

Ta b le 4

The percentage of 'Bancroft' variety apples affected by $B$. cinerea after 4 months of storage at $2 \mathrm{C}$

\begin{tabular}{ccc}
\hline \multirow{2}{*}{ Combination } & \multicolumn{2}{c}{ Locality } \\
\cline { 2 - 3 } & Skierniewice & Dąbrowicc \\
\hline 1 - control (no inoculation) & $6.8 \mathrm{a}^{*}$ & $2.5 \mathrm{a}$ \\
$\mathrm{II}$ - inoculation of flowers & $9.7 \mathrm{ab}$ & $6.2 \mathrm{~b}$ \\
III - Euparen + inoculation of & & $3.9 \mathrm{ab}$ \\
$\quad$ flowers & - & $4.0 \mathrm{ab}$ \\
IV - inoculation of sets & $7.0 \mathrm{ab}$ & $2.2 \mathrm{a}$ \\
V - inoculation of apples & $10.8 \mathrm{~b}$ & $8.6 \mathrm{~b}$ \\
VI - inocfore picking & & - \\
$\quad$ after picking & - &
\end{tabular}

* Statistical analysis was carried out separately for the experiments at Shierniewice and Dąrowice. $P=0.05$. 
Table 5

The occurrence of $B$. cinerea in the calyces of apples stored at $2^{\circ} \mathrm{C}$ for 4 months ( $\%$ colonized organs)

\begin{tabular}{|c|c|c|c|c|c|c|}
\hline \multirow[b]{2}{*}{ Calyx parts } & \multicolumn{4}{|c|}{ Combination } & \multirow[b]{2}{*}{$\begin{array}{c}\mathrm{V} \\
\text { inoculation of } \\
\text { apples before picking }\end{array}$} & \multirow[b]{2}{*}{$\begin{array}{c}\text { VI } \\
\text { inoculation of } \\
\text { apples after picking }\end{array}$} \\
\hline & $\begin{array}{c}\text { I } \\
\text { control (no inocu- } \\
\text { lation) }\end{array}$ & $\begin{array}{l}\text { II } \\
\text { inoculation of } \\
\text { flowers }\end{array}$ & $\begin{array}{c}\text { III } \\
\text { Euparen }+ \text { inocula- } \\
\text { tion of flowers }\end{array}$ & $\begin{array}{c}\text { IV } \\
\text { inoculation } \\
\text { of sets }\end{array}$ & & \\
\hline \multicolumn{7}{|l|}{ Skierniewice } \\
\hline Pistil & $8.0 \mathrm{a}^{*}$ & $50.0 \mathrm{c}$ & - & $10.0 \mathrm{a}$ & $8.0 \mathrm{a}$ & - \\
\hline Stamens & $6.0 \mathrm{a}$ & $44.0 \mathrm{bc}$ & $\mp$ & $6.0 \mathrm{a}$ & $10.0 \mathrm{a}$ & - \\
\hline Sepals & $14.0 \mathrm{a}$ & $36.0 \mathrm{~b}$ & - & $14.0 \mathrm{a}$ & $18.0 \mathrm{a}$ & - \\
\hline \multicolumn{7}{|l|}{ Dąbrowice } \\
\hline Pistil & $5.0 \mathrm{a}$ & $33.0 \mathrm{bc}$ & $10.0 \mathrm{ab}$ & $10.0 \mathrm{ab}$ & $10.0 \mathrm{ab}$ & $17.0 \mathrm{ab}$ \\
\hline Stamens & $12.0 \mathrm{ab}$ & $45.0 \mathrm{c}$ & $8.0 \mathrm{ab}$ & $15.0 \mathrm{ab}$ & $15.0 \mathrm{ab}$ & $15.0 \mathrm{ab}$ \\
\hline Sepals & $13.0 \mathrm{ab}$ & $40.0 \mathrm{c}$ & $12.0 \mathrm{ab}$ & $15.0 \mathrm{ab}$ & $15.0 \mathrm{ab}$ & $20.0 \mathrm{~b}$ \\
\hline
\end{tabular}

* Statistical analysis was carried out separately for the experiments at Skicrniewice and Dąbrowice. $P=0.05$. 
developed from infected flowers were settled the most. In the remaining combinations, the degree of settlement was the same as in the control.

\section{DISCUSSION}

Botrytis cinerea often causes latent infection. This type of infection has been found in strawberries, raspberries and grapes ( $\mathrm{J}$ a r v is, 1977). The results of this study which demonstrate the presence of the fungus in apple calyces throughout the entire vegetation period, without symptoms of disease, indicate that the infection of apples by $B$. cinerea is also of a latent nature. The apples are infected in the orchard; the disease develops during storage.

The determination of the effectiveness of the inoculations done in the orchard on the basis of the number of rotten apples found during storage is very difficult in the case of $B$. cinerea because this fungus easily infects healthy apples which are in contact with the diseased ones. These are secondary infections leading to so-called "nests" or "pockets" of decaying fruits. That is why conclusions on the time of infection of apples should be drawn from boths methods - exposing nutrient medium to calyces and on the evaluation of the rotting of apples during storage.

The results obtained in this study permit the conclusion to be drawn that although infection of apples by $B$. cinerea can take place all through the vegetation season, two periods are most important. The first is during blooming. $B$. cinerea infects the flowers and develops mainly on the petals, stamens and pistils. Olivier and Bondoux (1970) found that $B$. cinerea spores already germinate on pistils after 4 hours. This is stimulated by apple pollen (Borecka and Millikan, 1973). When they are strongly affected, flowers undergo necrosis and dry up. Fruit develops from flowers affected to a lesser extent or from healthy ones. The fungus settles the stamens and pistils and remains in the apple calyx without evoking symptoms of disease.

The second important period during which apples may be attacked is just before or just after picking. Under natural conditions, infection of apples is more probable just before harvest due to the source of infection being present in the orchard. This is when the calyces (mainly the sepals) are infected. This is also when the spores are translocated to the apple skin. In other studies ( $\mathrm{Bryk}, 1982$ ) it was found that during the month preceding harvest, the percentage of apples on which $B$. cinerea spores were found rose 2.5 times.

The $B$. cinerea mycelium found in the apple calyx is very viable. $\mathrm{Van}$ den Berg and Lentz (1968) found that under conditions 
of high air humidity at $0^{\circ} \mathrm{C}$ with no source of nutrients, the mycelium remains viable for over 12 months. Under favorable conditions, the mycelium in the apple calyx penetrates into the flesh causing it to rot. The reasons why the latent fungus becomes invasive and causes the disease are not known exactly. Certain hypotheses on this subject are presented by Verhoeff (1978).

\section{REFERENCES}

Berg L. van den, Lentz C. P., 1968. The effect of relative humidity and temperature on survival and growth of Botrytis cinerea and Sclerotinia sclerotiorum. Can. J. Bot. 46: 1477-1481.

B orecka H., Millikan D. F., 1973. Stimulatory effect of pollen and pistillate parts of some horticultural species upon the germination of Botrytis cinerea spores. Phytopath. 63: 1431-1432.

Bryk H., 1982. Grzyb Botryotinia fuckeliana (de Bary) Whetzel (Botrytis cinerea Pers.) jako czynnik chorobotwórczy na jablkach w okresie przechowywania. Ph. D. thesis. ISK Skierniewice.

J a rvis W. R., 1977. Botryotinia and Botrytis species: taxonomy, physiology, and pathogenicity. Research Branch, Can. Dep. Agric., Monograph No 15.

Morgat M., Mourichon Y., Saindrenan P., Bompeix G., 1977. Le point sur la lutte contre les pourritures des pommes et des poires en conservation. Arboric. fruit. 24 (283): 27-34.

Olivier J. M., B ondoux P., 1970. Infections stigmatiques chez quelques parasites des arbres fruitiers. C. R. Hebd. Seanc. Acad. Agric. Fr. 56: 1100$110 \overline{5}$.

Pierson C. F., Ceponis M. J., M c Colloch L. P., 1971. Market diseases of apples, pears, and quinces. U.S. Dep. Agric., Agric. Handb. 376: 42-43.

Tronsmo A., Raa J., 1977. Life cycle of dry eye rot pathogen Botrytis cinerea Pers. on apple. Phytopath. Z. 89: 203-207.

Vernoeff K., 1978. Latent infection. 3rd Int. Con. of Plant Pathology, München, 1978. Abstracts of Papers, p. 261.

Wilkins on E. H., 1943. Dry eye rot of apples caused by Botrytis cinerea Pers. J. Pomol. Hort. Sci. 20: 84-88.

Termin infekcji jabłek przez Botrytis cinerea Pers

Streszczenie

Celem badań było ustalenie terminu zakażenia jabłek przez Botrytis cinerea Pers. Wykonano sztuczne inokulacje zawiesiną zarodników konidialnych grzyba w różnych stadiach rozwoju jabłek (kwiaty, związki owocowe, wyrośnięte jabłka). Po zbiorze jablka przechowywano $w$ chłodni, $w$ temperaturze $2^{\circ} \mathrm{C}$, przez 4 miesiące, a następnie oceniano ich gnicie na skutek porażenia przez $B$. cinerea. Przez cały okres wegetacji śledzono obecność grzyba w kielichach jabłek wykła- 
dając na pożywkę agarowo-ziemniaczaną (PDA) kielichy wycięte $z$ zawiązków i jablek. Stwierdzono, że zakażenie jabłek przez $B$. cinerea może mieć charakter ukryty. Do zakażenia dochodzi w sadzie; grzyb pozostaje ukryty w kielichu jabłka nie wywolując objawów chorobowych, a dopiero w trakcie przechowywania jabłek wnika do miąższu powodując jego gnicie. Zakażenie jabłek może nastąpić w ciągu całego okresu wegetacji, jednak najważniejsze są dwa terminy - pierwszy to kwitnienie jabłoni, a drugi — przed lub bezpośrednio po zbiorze owoców. 